\title{
Etiology of cardiovascular disease in patients with schizophrenia: current perspectives
}

\author{
This article was published in the following Dove Press journal: \\ Neuropsychiatric Disease and Treatment \\ I October 2015 \\ Number of times this article has been viewed
}

\author{
Murat Emul' \\ Tevfik Kalelioglu² \\ 'Department of Psychiatry, Medical \\ School of Cerrahpasa, Istanbul \\ University, ${ }^{2}$ Department of Psychiatry, \\ Bakırkoy Mental Health Research and \\ Training Hospital, Istanbul, Turkey
}

\begin{abstract}
Cardiovascular morbidity and mortality are important problems among patients with schizophrenia. A wide spectrum of reasons, ranging from genes to the environment, are held responsible for causing the cardiovascular risk factors that may lead to shortening the life expectancy of patients with schizophrenia. Here, we have summarized the etiologic issues related with the cardiovascular risk factors in schizophrenia. First, we focused on heritable factors associated with cardiovascular disease and schizophrenia by mentioning studies about genetics-epigenetics, in the first-episode or drug-naïve patients. In this context, the association and candidate gene studies about metabolic disturbances in schizophrenia are reviewed, and the lack of the effects of epigenetic/posttranscriptional factors such as microRNAs is mentioned. Increased rates of type 2 diabetes mellitus and disrupted metabolic parameters in schizophrenia are forcing clinicians to struggle with metabolic syndrome parameters and related issues, which are also the underlying causes for the risk of having cardiometabolic and cardiovascular etiology. Second, we summarized the findings of metabolic syndrome-related entities and discussed the influence of the illness itself, antipsychotic drug treatment, and the possible disadvantageous lifestyle on the occurrence of metabolic syndrome (MetS) or diabetes mellitus. Third, we emphasized on the risk factors of sudden cardiac death in patients with schizophrenia. We reviewed the findings on the arrhythmias such as QT prolongation, which is a risk factor for Torsade de Pointes and sudden cardiac death or P-wave prolongation that is a risk factor for atrial fibrillation. For example, the use of antipsychotics is an important reason for the prolongation of QT and some other cardiac autonomic dysfunctions. Additionally, we discussed relatively rare issues such as myocarditis and cardiomyopathy, which are important for prognosis in schizophrenia that may have originated from the use of antipsychotic medication. In conclusion, we considered that the studies and awareness about physical needs of patients with schizophrenia are increasing. It seems logical to increase cooperation and shared care between the different health care professionals to screen and treat cardiovascular disease (CVD)-risk factors, MetS, and diabetes in patients with psychiatric disorders, because some risk factors of MetS or CVD are avoidable or at least modifiable to decrease high mortality in schizophrenia. We suggested that future research should focus on conducting an integrated system of studies based on a holistic biopsychosocial evaluation.
\end{abstract}

Keywords: antipsychotic, cardiovascular risk, MetS, miRNA, QTc, schizophrenia

\section{Introduction}

Cardiovascular death is a major contributor to the increased mortality rate (two- to threefold) and to the decreased life expectancy of $20 \%$ in schizophrenia victims according to normal population. ${ }^{1-3}$ The causes for increasing the mortality rate in schizophrenia victims are mostly similar to those in the general population with metabolic syndrome and diabetes mellitus. In addition, some disease-specific risk factors may also contribute to the increasing mortality rate such as follows: being genetically liable or having overlapping genes between cardiovascular disease, sudden cardiac
Correspondence: Murat Emul Department of Psychiatry, Medical School of Cerrahpasa, Istanbul University, Kocamustafapașa Cad. No 53, 34098 Istanbul, Turkey Email hmuratemul@hotmail.com 
death and schizophrenia. Requiring antipsychotic drugs and outcomes of such drugs, lifestyle due to negative symptoms, smoking, and alcohol abuse, and inability to obtain good medical care or inability to reach qualitative medical opportunities might also add some risks. In this review, we conducted a retrospective database study to assess the primary potential risk factors of cardiac mortality in firstepisode and chronic patients with schizophrenia in light of recent findings in the literature.

\section{Methods}

We conducted a systematic search for potentially relevant articles published between the year 1995 and 2015. Our search strategy was to assess the studies in earlier stages of schizophrenia including first-episode psychosis/schizophrenia, first-degree relatives, schizophrenia and cardiac mortality (single nucleotide polymporhisms or microRNA (miRNA) or modifiable risk factors or sudden death or QTc, or P-wave, Torsade de Pointes [TdP]), and glucose or insulin or cholesterol or triglycerides, or blood pressure or weight using health-related databases such as MEDLINE (via PubMed), Embase, and PsycINFO. We have focused on risk factors for mortality and we included systematic reviews, meta-analyses, and studies. We did not attempt to identify unpublished work or search in non-English- written journals.

\section{Findings about genetic and epigenetic mechanisms}

The increase in cardiovascular risk factors has also been revealed in antipsychotic naïve first-episode patients, ${ }^{4}$ before antipsychotic drug invention in the $1920 \mathrm{~s}^{5}$ and even in their healthy relatives. ${ }^{6}$ Thus, one may consider whether some common candidate genes are present or not between schizophrenia and cardiovascular risk-prone victims (Table 1).

Atypical antipsychotic-related weight gain was revealed to be associated with INSIG $2,{ }^{7}$ or the interaction of INSIG2 with INSIG1. ${ }^{8}$ The same investigators detected a significant association between rs498177 single nucleotide polymorphism (SNP) in the serotonin 5-HT2C receptor gene and metabolic syndrome only in female patients with schizophrenia. ${ }^{9}$ An association was shown between the endothelial nitric oxide synthetase (eNOS) T-786C genetic variant and endothelial functioning, which was no longer detectable if patients met the criteria of metabolic syndrome. ${ }^{10}$

Besides possible cardiovascular outcomes, in a genomewide association study (GWAS), common SNPs in the cardiomyopathy-associated gene (CMYA5) were also accused for

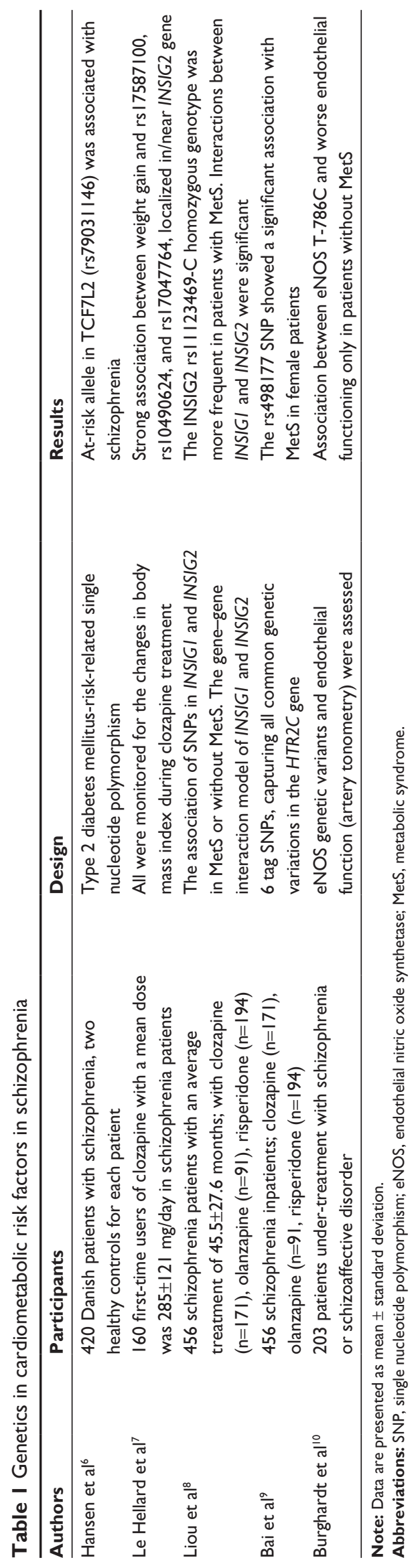


schizophrenia. ${ }^{11}$ Some authors have revealed an association between rs10503929 within the NRG1 gene and sudden unexpected deaths due to ventricular fibrillation in schizophrenia victims. ${ }^{12-14}$ In a five-drug-specific GWAS, genome-wide significance was detected with SNP rs4959235 at SLC22A23 which mediated the effects of quetiapine on QTc prolongation in patients from the Clinical Antipsychotic Trial of Intervention Effectiveness (CATIE) study (Table 2). ${ }^{15}$

miRNAs are small noncoding RNAs that bind to the 30-UTR (untranslated region) of usually many messenger RNAs. Through multiple mechanisms affecting transcription and translation, miRNAs are among the key regulators of posttranscriptional gene expression. ${ }^{16}$ In a systematic review, different alterations among miRNA were reported in the postmortem brains of schizophrenia patients. ${ }^{17}$ Perkins et al have investigated alterations of miRNAs in 179 rats treated with haloperidol and detected increments of miR-199a, miR128a, and miR-128b. ${ }^{18}$ On the contrary, the downregulation of miR-31 and miR-342-5p was shown in peripheral blood mononuclear cells in vivo in schizophrenia patients. ${ }^{19}$ In a recent study, for the first time, the alteration of miRNAs after olanzapine has been found to be associated with metabolic pathway via pathway analysis in mice. ${ }^{20}$

\section{Findings on cardiometabolic risk factors}

Data from the general population estimated five metabolic risk factors for predisposition to cardiovascular disease (CVD) approximately twofold increase ${ }^{21}$ and to diabetes approximately three- to fourfold increase $e^{8,22}$ and widely shaped as: abdominal obesity, elevated triglycerides, reduced high density lipoprotein (HDL) cholesterol, high blood pressure, and elevated fasting blood glucose levels.

In a systematic review of 25 studies in which the average follow-up duration was 31.7 weeks (from January 1990 to June 15, 2010), no difference in metabolic syndrome (MetS) was detected in drug-naïve patients than healthy controls. ${ }^{1}$ On the contrary, some authors had found a higher waist/hip ratio $^{23,24}$ and more visceral fat ${ }^{25}$ in first-episode patients with schizophrenia than controls although inadequate control matching was an important limitation of these studies. The European First Episode Schizophrenia Trial (EUFEST) was a 1-year open label study in which first-episode ( $<2$ years) or partially antipsychotic naïve patients were recruited. Partially antipsychotic naïve was defined as the use of any antipsychotic drug $<2$ weeks in the previous year or $<6$ week antipsychotic treatment at any time including haloperidol, amisulpride, ziprasidone, quetiapine and olanzapine. In that study, the baseline rate of MetS was similar in the drug-naïve and brief antipsychotic use groups and in the general population in Europe (Table 3). Interestingly, $58.5 \%$ of the patients have shown individual risk factors for one or more elevated metabolic risks at the baseline as following: $28.5 \%$ suboptimal HDL, $24.2 \%$ hypertension, $17.7 \%$ hyper-triglyceridemia, $8.2 \%$ abdominal obesity, and $7.3 \%$ hyperglycemia. ${ }^{28} \mathrm{~A}$ meta-analysis was performed with 126 valid analyses from 77 published studies $(n=25,692)$ and data from 14 of these 77 studies $(n=800)$ were included for analysis which had examined first-episode psychosis and/or

Table 2 Genetics in cardioautonomic risk factors

\begin{tabular}{|c|c|c|c|}
\hline Authors & Participants & Design & Results \\
\hline Chen et al'" & $\begin{array}{l}25 \text { samples with a total of } 33,834 \text { subjects, } \\
\text { including } 912 \text { families with } 4,160 \text { subjects, } \\
13,038 \text { cases and } 16,636 \text { controls }\end{array}$ & $\begin{array}{l}\text { GWA analyses study in the CMYA5 } \\
\text { gene }\end{array}$ & $\begin{array}{l}\text { rsI0043986 and rs } 470459 \text { I were } \\
\text { significantly associated with } \\
\text { schizophrenia }\end{array}$ \\
\hline $\begin{array}{l}\text { Nicodemus } \\
\text { et } \mathrm{al}^{12}\end{array}$ & $\begin{array}{l}296 \text { schizophrenia, } 365 \text { healthy controls } \\
\text { and a separate sample of controls for } \\
\text { neuroimaging }(n=172)\end{array}$ & $\begin{array}{l}\text { Association between SNPs and the } \\
\text { relationship between SNPs and BOLD } \\
\text { during the working memory by } \mathrm{FMRI}\end{array}$ & $\begin{array}{l}\text { Interaction between NRGI } 5^{\prime} \\
\text { and rs } 456075 \text { I-rs3802160 and } \\
\text { schizophrenia, validated using fMRI } \\
\text { of working memory }\end{array}$ \\
\hline $\begin{array}{l}\text { Huertas- } \\
\text { Vazquez et al }{ }^{14}\end{array}$ & $\begin{array}{l}\text { Oregon study, } 340 \text { SCD cases presenting } \\
\text { with ventricular fibrillation and } 342 \\
\text { controls }\end{array}$ & $\begin{array}{l}\text { I7 SNPs mapped to I } 4 \text { loci related } \\
\text { with schizophrenia and epilepsy was } \\
\text { tested }\end{array}$ & $\begin{array}{l}\text { SNP rs I } 0503929 \text { within the NRGI } \\
\text { gene was associated with SCD }\end{array}$ \\
\hline Aberg et $\mathrm{al}^{15}$ & $\begin{array}{l}492,000 \text { SNP genotypes from } 738 \\
\text { schizophrenia patients from the CATIE } \\
\text { study }\end{array}$ & $\begin{array}{l}\text { Antipsychotic-induced QTc } \\
\text { prolongation; a GWA study }\end{array}$ & $\begin{array}{l}\text { Association of rs } 4959235 \text { and } \\
\text { quetiapine/QTc within gene } \\
\text { SLC22A23 }\end{array}$ \\
\hline Santarelli et $\mathrm{al}^{20}$ & $\begin{array}{l}\text { miRNA profile in mice treated with } \\
\text { haloperidol }(n=I I) \text {, olanzapine }(n=I I) \\
\text { or clozapine }(n=\mid 2) \text { for } 7 \text { days and saline } \\
\text { group }(n=I I)\end{array}$ & $\begin{array}{l}45 \text { total mouse whole brain RNA } \\
\text { samples were used for microarray } \\
\text { profiling }\end{array}$ & $\begin{array}{l}\text { Down regulation of miR-193, } \\
\text { miR-223, miR-544 in DLPC } \\
\text { by olanzapine; upregulation of } \\
\text { miRNA-339 in BA22 in haloperidol }\end{array}$ \\
\hline
\end{tabular}

Abbreviations: GWA, genome-wide association; SNP, single nucleotide polymorphism; RNA, ribonucleic acid; miRNA, microRNA; QTc, heart rate-corrected QT interval; CATIE, Clinical Antipsychotic Trial of Intervention Effectiveness; fMRI, functional magnetic resonance imaging; SCD, sudden cardiac death; DLPFC, dorsolateral prefrontal cortex; BOLD, blood oxygen level-dependent. 
Table 3 Cardiometabolic risk factors in first-episode psychosis

\begin{tabular}{|c|c|c|c|}
\hline Authors & Participants & Design & Results \\
\hline Foley et al' & $\begin{array}{l}\text { Drug naïve or with a short-time } \\
\text { drug treatment, sample size } \\
\text { varied }(n=9-555)\end{array}$ & $\begin{array}{l}\text { Review of } 25 \text { longitudinal } \\
\text { studies and of which } 8 \\
\text { have controls }\end{array}$ & $\begin{array}{l}\text { No difference in cardiometabolic indices; } \\
\text { risk increases after first exposure to any } \\
\text { antipsychotics }\end{array}$ \\
\hline Correll et a $\left.\right|^{2}$ & $\begin{array}{l}\text { Patients in FES programs, } \\
\text { had less than } 6 \text { months of } \\
\text { antipsychotic treatment }\end{array}$ & $\begin{array}{l}\text { Baseline findings in the } \\
\text { RAISE study }\end{array}$ & $\begin{array}{l}\text { I3.2\% of FES patients met the criteria of } \\
\text { MetS }\end{array}$ \\
\hline Saddichha et $\mathrm{a}^{23}$ & $\begin{array}{l}66 \text { FEP patients initiating to } \\
\text { olanzapine, haloperidol, or } \\
\text { risperidone }\end{array}$ & $\begin{array}{l}\text { Randomized, case-control } \\
\text { and a prospective study } \\
\text { (for a period of } 6 \text { weeks) }\end{array}$ & $\begin{array}{l}\text { Baseline obesity prevalence was } 30 \text { times } \\
\text { higher in patients; olanzapine, } 5.1 \mathrm{~kg}> \\
\text { risperidone, } 4.1 \mathrm{~kg}>\text { haloperidol, } 2.8 \mathrm{~kg}\end{array}$ \\
\hline Ryan et $\mathrm{a}^{25}$ & $\begin{array}{l}19 \text { drug naïve, FEP patients, and } \\
19 \text { matched controls, started to } \\
\text { receive olanzapine or risperidone }\end{array}$ & $\begin{array}{l}\text { Fatness and fat } \\
\text { distribution parameters } \\
\text { were measured }\end{array}$ & $\begin{array}{l}\text { Baseline intra-abdominal fat was significantly } \\
\text { higher in patients; no significant increase in } \\
\text { intra-abdominal fat distribution after atypicals }\end{array}$ \\
\hline Fleischhacker et $\mathrm{al}^{26}$ & $\begin{array}{l}498 \text { patients with FEP, EUFEST } \\
\text { study; visits at the 13th, 26th, } \\
\text { 39th and } 52 \text { nd weeks }\end{array}$ & $\begin{array}{l}\text { I-year open label study } \\
\text { including baseline MetS } \\
\text { indices }\end{array}$ & $\begin{array}{l}\text { Baseline MetS prevalence was } 5.7 \% \text { in } \\
\text { drug-naïve and } 6.1 \% \text { in briefly antipsychotics } \\
\text { exposed patients }\end{array}$ \\
\hline
\end{tabular}

Abbreviations: FES, first-episode schizophrenia; FEP, first-episode psychosis; EUFEST, European First Episode Schizophrenia Trial; MetS, metabolic syndrome; RAISE, Recovery After an Initial Schizophrenia Episode.

drug-naïve patients. Although no comparison with general population was detected within all these 14 studies, the MetS rate was established to be $11.3 \%(95 \% \mathrm{CI}=7.3 \%-16.1 \%)^{27}$ that was surprisingly lower, while the estimated prevalence of the MetS rate in Europe was $18 \%-20 \%{ }^{28}$ and $25 \%$ in the general population in the USA. ${ }^{29}$

It is commonly accepted that the prevalence of MetS in patients with chronic schizophrenia is higher than that in the normal population. In the CATIE study, the rate of MetS in schizophrenia was found to be $40.9 \%$ vs $23.7 \%$ in controls (for males $36.0 \%$ vs $19.7 \%$; for females $51.6 \%$ vs $25.1 \%) .^{30} \mathrm{In}$ the aforementioned meta-analysis (126 analyses from 77 published studies, $n=25,692$ ), the overall rate of MetS was 32.5\% (34.8\% in males and 34.8\% in females). Additionally, MetS was present in $39.2 \%$ of older patients with a mean age of 50 years or above ${ }^{27}$ which shows that the MetS rate is rising with aging in patients with schizophrenia (Table 4).
The overall findings according to this meta-analysis were as follows: the rate of being overweight was $49.4 \%$ $(\mathrm{N}=53)$ and $44.4 \%(\mathrm{~N}=8)$ according to two different criteria of waist circumference measurement. Hyperglycemia was detected in $19.5 \%$ of patients $(\mathrm{N}=147, \mathrm{n}=13,784)$, while increased triglyceride was $39.3 \%(\mathrm{~N}=77, \mathrm{n}=19,831)$, decreased HDL was $42.6 \%(\mathrm{~N}=76, \mathrm{n}=19,280)$, high blood pressure was $38.7 \%(\mathrm{~N}=72, \mathrm{n}=18,657)$, and presence of diabetes was $10.9 \%(\mathrm{~N}=14, \mathrm{n}=2,186) .{ }^{27}$ In addition, the rate of diabetes was reported as being $16 \%$ in females and $11 \%$ in males with schizophrenia, and only $3 \%$ in controls, ${ }^{31}$ or reported to be $2.5-3$-fold higher in the 1990 s even before the extensive presence of atypical antipsychotics on the counter. ${ }^{32}$

In the EUFEST study, the patients had a significantly greater weight gain and increased waist circumference in amisulpride and haloperidol groups than the ziprasidone group at weeks 26, 39, and 52, while no significant change

Table 4 Cardiometabolic risk factors in patients with chronic schizophrenia

\begin{tabular}{|c|c|c|c|}
\hline Authors & Participants & Design & Results \\
\hline McEvoy et $\mathrm{al}^{30}$ & $\begin{array}{l}\mathrm{n}=689 \text { chronic patients with } \\
\text { schizophrenia }\end{array}$ & $\begin{array}{l}\text { CATIE, a national, multisite, prospective } \\
\text { trial of anti-psychotic effectiveness }\end{array}$ & $\begin{array}{l}\text { Baseline MetS was } 40.9 \%-42.7 \% \text { in patients, } \\
23.7 \% \text { in normal subjects }\end{array}$ \\
\hline Goff et $\mathrm{al}^{31}$ & $\begin{array}{l}\mathrm{n}=689 \text { chronic patients with } \\
\text { schizophrenia }\end{array}$ & CATIE & $\begin{array}{l}\text { The presence of diabetes was } 13 \% \text { and } 3 \% \\
\text { in normal subjects }\end{array}$ \\
\hline Dixon et $\mathrm{al}^{32}$ & $\begin{array}{l}\text { Large population under treatment } \\
\text { for schizophrenia }(n=20,248)\end{array}$ & $\begin{array}{l}\text { The schizophrenia Patient Outcomes } \\
\text { Research Team study }\end{array}$ & $\begin{array}{l}\text { The rate of diabetes was found to be } 2.5-3- \\
\text { fold higher than general population }\end{array}$ \\
\hline Arranz et $\mathrm{al}^{35}$ & $\begin{array}{l}\text { Patients with schizophrenia; } \\
\text { standard olanzapine tablets }(n=19) \text {, } \\
\text { and disintegrating olanzapine }(n=19)\end{array}$ & Prospective study (6 weeks) & $\begin{array}{l}\text { Significant increase in weight } 6.3 \pm 1.9 \mathrm{~kg} \text { vs } \\
3.3 \pm 3.2 \mathrm{~kg} \text { and in BMI } 2.1 \mathrm{~kg} / \mathrm{m}^{2} \mathrm{vs} 1.1 \mathrm{~kg} / \mathrm{m}^{2} \\
\text { in standard than disintegrating olanzapine }\end{array}$ \\
\hline Hägg et $\mathrm{al}^{37}$ & $\begin{array}{l}269 \text { under-treatment patients with } \\
\text { schizophrenia }\end{array}$ & $\begin{array}{l}\text { A cross-sectional Northern Sweden } \\
\text { study }\end{array}$ & $\begin{array}{l}\text { MetS was } 34.6 \% \text { and the highest in } \\
\text { clozapine-treated patients, ie, } 48 \%\end{array}$ \\
\hline
\end{tabular}

Note: Data are presented as mean \pm standard deviation.

Abbreviations: CATIE, clinical antipsychotic trial of intervention effectiveness; MetS, metabolic syndrome; BMI, body mass index. 
was detected with respect to weight gain between groups at the first visit. Besides, weight gain and waist circumference were significantly higher at each time-point in the olanzapine and quetiapine groups than in the ziprasidone group. ${ }^{26}$ In this study, no significant changes were seen between antipsychotic trial groups with respect to the blood levels of glucose, total cholesterol, triglyceride, and HDL. However, in a systematic review of FEP trials, the influences of antipsychotic drugs were tested in 25 studies in which the average follow-up time across was 31.7 weeks (ranged from 4 weeks to 2.5 years). Significant changes were common at the sixth month with regard to the total body weight, HDL, low density lipoprotein (LDL), triglycerides, fasting glucose and insulin levels. ${ }^{1}$ In this review, the weight gain in olanzapine $(5-6 \mathrm{~kg}$ ) was significantly higher than risperidone (4 kg), and haloperidol ( $3 \mathrm{~kg}$ ) at weeks $6-8$, while the difference between olanzapine and risperidone was waned at weeks $12-16$ (7-9 kg vs $6 \mathrm{~kg}$, respectively). ${ }^{1}$ The weight gain did not differ for 1 year across olanzapine, risperidone, clozapine, amisulpride, quetiapine fumarate, and haloperidol. ${ }^{1}$ Interestingly, a question was raised as to whether orally disintegrating tablets may have lesser effects on weight gain or not than standard tablets (Table 4). ${ }^{35}$ Although the number of hyperglycemia cases had increased after 52 weeks in the first episode of the psychosis Comparison of Atypicals in First Episode of Psychosis (CAFÉ) study ${ }^{36}$ and small amounts of increases in the blood glucose level was noted in the EUFEST ${ }^{28}$ study groups, no difference was informed between various first- and second-generation antipsychotics. Risperidone was related to the smallest elevations of the triglyceride level in fasting and the smallest reduction in the HDL level than the other comparators such as olanzapine and quetiapine in the CAFÉ study. ${ }^{36}$
The pathophysiology of the underlying MetS is not clear due to antipsychotic use, and an increased risk of CVD cannot be exactly attributed to antipsychotics or sociodemographical aspects of patients with schizophrenia. ${ }^{34}$ In a Sweden study, the MetS rate was higher in chronic patients treated with clozapine. ${ }^{39}$ In CATIE study ( $\left.n=689\right)$, at the time of assessment, the groups were as follows: $24.8 \%$ were drug free/-naïve, 58.4\% were taking an atypical antipsychotic, $11.9 \%$ were under conventional antipsychotic treatment, and $5.0 \%$ were taking a combination of antipsychotics. It was found that diabetes mellitus and hypertension and a significantly lower HDL level was significantly more frequent in patients with schizophrenia than that in controls. ${ }^{33}$ In the seminal meta-analysis of Mitchell et al $(\mathrm{N}=112$ studies and $\mathrm{n}=24,892$ patients), 35.3\% frequency of MetS in all schizophrenia patients and a $39.2 \%$ frequency of MetS in older patients ( $\mathrm{N}=14, \mathrm{n}=6,396)$ have been reported. ${ }^{27}$ According to this meta-analysis, using Adult Treatment Panel III criteria, only three drug monotherapy comparisons were possible: the MetS rate was $51.9 \%(\mathrm{~N}=13, \mathrm{n}=673)$ for clozapine; $28.2 \%$ $(\mathrm{N}=12, \mathrm{n}=1,056)$ for olanzapine; and $27.9 \%(\mathrm{~N}=9, \mathrm{n}=659)$ for risperidone. However, the finding of clozapine in this meta-analysis might have confounders as old age and a longer duration of illness. ${ }^{27}$

\section{Findings on cardiomyopathic risk factors and sudden cardiac death}

In 1899, Emil Kraepelin mentioned extensive autonomic alterations in patients with schizophrenia, such as increased heart rates, altered pupillary function, increased sweating and salivation, and body temperature changes; these described signs suggest increased sympathetic output, decreased parasympathetic modulation, or both. ${ }^{38}$

Table 5 Cardiomyopathic risk factors in first-episode schizophrenia or at risk populations

\begin{tabular}{|c|c|c|c|}
\hline Authors & Participants & Design & Results \\
\hline Emul et $\mathrm{al}^{39}$ & $\begin{array}{l}\text { Schizophrenia inpatients }(\mathrm{n}=\mathrm{I} \mathrm{I}) \\
\text { drug free }(<4 \text { weeks), I I controls }\end{array}$ & $\begin{array}{l}\text { ECG reports prior to ziprasidone and } \\
\mathrm{I} .5-2 \mathrm{~h} \text { after an IM injection }\end{array}$ & $\begin{array}{l}\text { Baseline P-wave dispersion was significantly } \\
\text { longer in patients; no changes after ziprasidone } \\
\text { IM have detected among ECG variables }\end{array}$ \\
\hline Toichi et al $^{40}$ & $\begin{array}{l}53 \text { chronic patients ( } n=22 \text { acute } \\
\text { psychotic attack, } n=31 \text {, stable), } \\
53 \text { healthy controls }\end{array}$ & $\begin{array}{l}\text { In ECG, cardiac autonomic functions } \\
\text { were based on heartbeat intervals }\end{array}$ & $\begin{array}{l}\text { In psychotic attack, parasympathetic index } \\
\text { was significantly decreased without significant } \\
\text { changes in the sympathetic index }\end{array}$ \\
\hline Bär et $\mathrm{al}^{41}$ & $\begin{array}{l}\text { Paranoid schizophrenia }(n=36) \text {, } \\
36 \text { first-degree relatives, controls } \\
(n=36)\end{array}$ & Cross-sectional, case-control study & $\begin{array}{l}\text { Evidence for reduced } \mathrm{HRV} \text { as well as } \\
\text { augmented QT variability in first-degree } \\
\text { relatives }\end{array}$ \\
\hline Jindal et $\mathrm{al}^{42}$ & $\begin{array}{l}24 \text { neuroleptic-naïve FEP patients, } \\
26 \text { controls }\end{array}$ & $\begin{array}{l}\text { ECG data were collected between } \\
8 \text { and } 10 \text { am }\end{array}$ & $\begin{array}{l}\text { Significantly increased QTV and decreased } \\
\text { RRV. No correlation between psychotic } \\
\text { symptom severity and HRV abnormalities }\end{array}$ \\
\hline Zhao et $\mathrm{al}^{48}$ & $\begin{array}{l}27 \mathrm{FEP} \text {, the initiation of oral } \\
\text { ziprasidone (up to } 120-160 \mathrm{mg} / \text { day) }\end{array}$ & $\begin{array}{l}\text { Prospective, } 8 \text { weeks; I } 6 \text { dropped } \\
\text { out; data of II patients were analyzed }\end{array}$ & $\begin{array}{l}\text { The mean QT prolongation was } 20 \mathrm{~ms} \text {, no } \\
\text { QTc prolongation }>500 \mathrm{~ms}\end{array}$ \\
\hline
\end{tabular}

Abbreviations: ECG, electrocardiogram; RRV, RR interval variability; QTc, heart beat-corrected QT interval; FEP, first-episode psychosis; h, hour; IM, intramuscular; HRV, heart rate variability; QTV, QT interval variability; QT, QT interval. 
In the last 2 decades, the compromised autonomic system in schizophrenia patients ${ }^{38-40}$ and in first-degree relatives of patients with schizophrenia ${ }^{43}$ has been accused for a number of cardiac abnormalities (Table 5). Autonomic dysfunction is most likely the consequence of long-lasting stressful experiences associated with the psychotic state, in addition to a genetic underlying predisposition to autonomic dysfunction as observed in the relatives of patients. ${ }^{38}$ For example, decreased RR interval variability (RRV), which is a marker for cardiac parasympathetic activity, has been reported to predict potential fatal ventricular tachycardia. ${ }^{42}$ Depression with psychotic features in a Finnish study ${ }^{43}$ has also been suggested as a risk factor for sudden death and other arrhythmic events. ${ }^{44}$ Jindal et al concluded that drug-naïve patients with first-episode psychosis may have an impaired cardiac autonomic function. ${ }^{42}$

In a meta-analysis study, antipsychotics were reported to increase risk by two- to sixfold for ventricular arrhythmias, sudden cardiac death, and lengthening of heart ratecorrected QT interval (QTc), and it has been widely accepted as a marker of predicting drug-associated cardiac events ${ }^{45}$ although no clear evidence for the QT interval prolongation $(>500 \mathrm{~ms})$ is related with increased risk for TdP - an increased risk of ventricular tachyarrhythmia - or sudden cardiac death. ${ }^{44,46}$ Some questions rise whether there is any difference between atypical and typical antipsychotic drugs in the literature. ${ }^{47}$ In a recently published study, no meaningful changes after ziprasidone use was detected in 27 first-episode psychosis (illness duration of $<3$ years, previous antipsychotic exposure lasting for $<2$ consecutive weeks). ${ }^{48}$

Indeed, the prolonged QT interval was detected in $8 \%-23 \%$ of patients under antipsychotics treatment and in $2 \%$ of healthy controls, while a dose-dependent correlation between the risk of QT lengthening effects and antipsychotic use has also been emphasized. ${ }^{49,50}$

In a meta-analysis study of seven atypicals (aripiprazole, amisulpride, sertindole, risperidone, quetiapine, olanzapine, and ziprasidone), the authors have collected data of 16 randomized controlled trials (RCTs) from 42 RCTs ${ }^{45}$ They have found that aripiprazole was the only atypical drug that shows both significantly smaller mean change in QTc $(P=0.03)$ and significantly lower risk to cause QTc prolongation $(P=0.04)$, while sertindole was informed with a significant QTc prolongation $(P<0.0001) .{ }^{45}$ In another study, the QTc interval prolongation effects were ranked as: thioridazine $>$ ziprasidone $>$ quetiapine $>$ risperidone $>$ olanzapine $>$ haloperidol. ${ }^{52}$ One of the main questions was sex differences, because it is well-known that females are more prone to QT prolongation as found in a study that the mean QTc interval was shorter in males $(391 \pm 31 \mathrm{~ms}$ vs $400 \pm 37 \mathrm{~ms}, P<0.001){ }^{52}$ In a recent study according to the mean QTc interval, the results were as follows: quetiapine $=$ olanzapine but quetiapine $>$ risperidone and aripiprazole, and olanzapine $>$ risperidone (Table 6). However, in this study,

Table 6 Cardiomyopathic risk factors in chronic schizophrenia and use of antipsychotic drugs

\begin{tabular}{|c|c|c|c|}
\hline Authors & Participants & Design & Results \\
\hline Harrigan et $\mathrm{al}^{51}$ & $\begin{array}{l}\text { Haloperidol }(\mathrm{n}=27) 15 \mathrm{mg} / \text { day; thioridazine } \\
(\mathrm{n}=30) 300 \mathrm{mg} / \text { day; ziprasidone }(\mathrm{n}=3 \mathrm{I}) \\
160 \mathrm{mg} / \text { day; quetiapine }(\mathrm{n}=27) 750 \mathrm{mg} / \text { day; } \\
\text { olanzapine }(\mathrm{n}=24) 20 \mathrm{mg} / \text { day, or risperidone } \\
6-8 \mathrm{mg} / \text { day increased to } 16 \mathrm{mg} / \text { day }(\mathrm{n}=25 / 20)\end{array}$ & $\begin{array}{l}\text { Psychotic patients, } \\
\text { open-label, randomized, } \\
\text { parallel-group, the } \\
\text { influences of } 6 \\
\text { antipsychotics on QTc }\end{array}$ & $\begin{array}{l}\text { None of drugs }>500 \mathrm{~ms} \text { on QTc; the mean QTc } \\
\text { increments: in thioridazine }(30.1 \mathrm{~ms}) \text {, in olanzapine } \\
(1.7 \mathrm{~ms}) \text {, in ziprasidone }(15.9 \mathrm{~ms}) \text {, in haloperidol } \\
(7.1 \mathrm{~ms}) \text {, in quetiapine it was }(5.7 \mathrm{~ms}) \text { and in } \\
\text { risperidone groups ( } 3.9 \mathrm{~ms} \text { and } 3.6 \mathrm{~ms})\end{array}$ \\
\hline Yang et al ${ }^{52}$ & $\begin{array}{l}\text { Under-treatment inpatients schizophrenia } \\
(n=1,006)(\text { male, } 689 \text { and female, } 317) \text { and } \\
\text { age- and sex-matched controls }(n=456)\end{array}$ & Naturalistic & $\begin{array}{l}\text { Prolonged QTc was } 4.5 \% \text {; }(3.2 \% \text { in males and } 7.3 \% \text { in } \\
\text { females); QTc in clozapine was significantly longer than } \\
\text { risperidone and typicals; QTc in risperidone = typical }\end{array}$ \\
\hline Suzuki et $\mathrm{al}^{53}$ & $\begin{array}{l}\text { Schizophrenia }(n=222) \text { with OLZ }(n=69) \text {, RIS } \\
(n=60) \text {, ARP }(n=62) \text {, or QTP }(n=31)\end{array}$ & $\begin{array}{l}\text { QTc interval in chronic } \\
\text { schizophrenic patients }\end{array}$ & $\begin{array}{l}\text { QTP }>\text { RIS }(P=0.002) \text { QTP }>\text { ARP }(P=0.029) \\
\text { OLZ }>\text { RIS }(P=0.006)\end{array}$ \\
\hline Hasnain et $\mathrm{a}^{56}$ & $\begin{array}{l}\text { Amisulpride }(n=83) \text {; clozapine }(n=73) \\
\text { quetiapine mono/combined }(n=286) \\
\text { risperidone }(n=45) \text {, ziprasidone }(n=56)\end{array}$ & $\begin{array}{l}\text { Overdoses of different } \\
\text { antipsychotics on QTc } \\
\text { and TdP }\end{array}$ & $\begin{array}{l}\text { Amisulpride, } 7 \% \text {, TdP; clozapine, } 8.2 \% \text { QTc } \\
\text { prolongation; quetiapine, } 8.4 \% \text { borderline QTc; } \\
\text { risperidone, } 58 \% \text { tachycardia ziprasidone, } 2 \% \mathrm{TdP} \text { and } \\
\text { I2.5\% borderline QTc prolongation }\end{array}$ \\
\hline Suzuki et $\mathrm{al}^{57}$ & 25 schizophrenia outpatients & $\begin{array}{l}\text { Follow-up study after } \\
\text { olanzapine use }\end{array}$ & $\begin{array}{l}\text { Significant increase in PR interval, not more than } \\
200 \mathrm{~ms} \text {; no significance in the QT interval }\end{array}$ \\
\hline Bayar et a ${ }^{59}$ & $\begin{array}{l}\text { I5 schizophrenia receiving antipsychotics, } \\
15 \text { controls }\end{array}$ & $\begin{array}{l}\text { ECG records at } \\
\text { baseline and after the } \\
\text { 3rd ECT }\end{array}$ & $\begin{array}{l}\text { Baseline P minimum duration was shorter in patients; } \\
\text { significant increase in P maximum duration after the } \\
\text { 3rd ECT; no changes after the 3rd ECT in P-wave } \\
\text { dispersion, QTc, and QT dispersion }\end{array}$ \\
\hline
\end{tabular}

Abbreviations: OLZ, olanzapine; RIS, risperidone; QTP, quetiapine QT interval; ECG, electrocardiogram; QTc, heart beat-corrected QT interval; TdP, Torsade de Pointes; $\mathrm{ECT}$, electroconvulsive therapy; ms, milliseconds; ARP, aripiprazole; $\mathrm{QT}, \mathrm{QT}$ interval. 
the mean chlorpromazine equivalent doses of olanzapine and quetiapine were significantly higher than risperidone and aripiprazole groups. In this study, the average QTc in females was significantly longer only in the olanzapine group. ${ }^{53}$ However, in a few studies, no sex difference in QTc was demonstrated in various antipsychotic use such as depot, atypical, or typicals. ${ }^{49,54,55}$

Although there are extensive studies on QTc, very few studies have emphasized on the PR interval in the literature. ${ }^{39,57}$ In fact, prolongation of the PR interval might lead to atrial fibrillation, pacemaker indication, and mortality. ${ }^{58}$ Emul et al have not found a difference on PR after intramuscular ziprasidone administration ${ }^{39}$ while a significantly increased PR interval after the third electroconvulsive therapy (ECT) session was reported in patients with schizophrenia who were under antipsychotic polypharmacy treatment ${ }^{61}$ or olanzapine is accounted for PR prolongation in a recent study. ${ }^{57}$

\section{Findings about sudden death due to cardiomyopathy related with antipsychotic drug use in schizophrenia}

In the literature, a widely accepted etiologic factor for cardiomyopathy is the use of clozapine. In a 11-year follow-up study, clozapine was found to be related with the lowest mortality rate and the fewest number of deaths due to ischemic cardiac disease than the most frequently used typical and atypical antipsychotic drugs. ${ }^{60}$ Previously, the rate of clozapine-related cardiomyopathy had been considered to be similar to that within the normal population $(8.9 / 100,000)$ in the USA. ${ }^{61}$ Now, the rate of clozapine-induced cardiomyopathy is demonstrated to be five times more frequent than that in the normal population. ${ }^{62}$ In a study after 10 years from the first described clozapine-induced cardiomyopathy, Reinders et al estimated the prevalence to be $9.6 \%$. This relatively high rate may be the real rate of clozapine-related cardiomyopathy because of the increase in the awareness of the clinicians. ${ }^{63}$ In case reports, usually myocarditis initiates within the first month of clozapine administration, independent from dosing with tachycardia, shortness of breath, cough, and fatigue symptoms in which $12.5 \%-24 \%$ may have mortal outcomes. ${ }^{63,64}$ In the literature, there are few individual case reports on cardiomyopathy due to antipsychotic use such as amisulpride, ${ }^{65}$ after quetiapine $(\mathrm{n}=3),{ }^{66-68}$ haloperidol, ${ }^{69}$ and risperidone. ${ }^{70}$

\section{Discussion}

Similar to schizophrenia, metabolic syndrome and cardiovascular symptoms in schizophrenia are also multifactorial and associated with the influences of multiple genes in combination with environmental factors. NRG1 is a signaling protein that mediates cell-cell interactions, which is a shared development process in schizophrenia and cardiac function. Interestingly, the minor allele of the non-synonymous SNP rs10503929 within the NRG1 gene was associated with sudden cardiac deaths. Functional polymorphisms in cytochrome P450, which play important roles in the metabolism of antipsychotic drugs, might be associated with prolongation of QTc. ${ }^{71}$ The $S L C 22 A 23$ gene expression is in the development of heart ${ }^{72}$ and SNPs in that the gene might be related with QT prolongation in some antipsychotics. However, there are some debates in genetic studies which were searching for the association of SNPs with schizophrenia: an association of polymorphism with schizophrenia might be a chance of observation, replication of the SNP findings are almost infrequent, the detected SNPs that are not specific to schizophrenia may also be involved in bipolar disorder, etc, in a relatively small sample size under psychiatric conditions (few hundreds to few thousands in GWAS vs $>50,000$ diabetes/cardiac studies). Thus, to boost the power of the associated SNPs in GWASs, some innovative statistical approaches are considered in recent studies aiming to neglect the need of larger and larger samples for detecting cardiovascular risk factors in schizophrenia, ${ }^{73,74}$ although the richest findings from GWAS may still have very limited power to predict the genetic variation in schizophrenia.

In the last decade, a new window is opened after the discovery of the role of miRNAs to molecular pathology of schizophrenia with related implication for metabolic syndrome, being the target of antipsychotic drugs and interaction of neurotransmitters including serotonin-dopamineglutamate. Changes in miRNA expression levels may reflect schizophrenia-related issues, conditions of high-risk individuals/first-episode psychotic, and/or intermediate targets of antipsychotic drug action that may lead to MetS, diabetes, and/or sudden cardiac death that are lacking in the literature. In addition, there are still no clinical and very few preclinical studies in association with miRNAs and after antipsychotic drug use. Thus, clarifying the potential role of miRNA in the pathophysiology of cardiovascular risks in schizophrenia might lead to the discovery of new therapeutic agents such as agonist miRNA (agomiR) or antagonist miRNA (antagomiR).

To clarify the related risk factors for increased MetS in patients with schizophrenia, drug-naïve patients or those who are at the very beginning stage of the illness and treatment seems crucial. In the literature, the findings seem far away 
from a consistent conclusion about glucose tolerance or insulin resistance in first-episode and/or drug-naïve patients. In addition, there is no consensus about the inclusion criteria of the first-episode psychosis/schizophrenia. Usually, the firstepisode studies do not prolong $>1$ year and high dropout rates in longer trials are major concerns. Meanwhile, inconclusive findings as impaired/non-impaired glucose tolerance or insulin resistance/no effect can be seen in the literature about first-episode and/or drug-naïve patients. However, a question rises about the slightly higher waist/hip ratio at the initial phase just prior to antipsychotic drugs that justify to be investigated. ${ }^{1}$ Thus, we considered that the prevalence of MetS rate is not increased at the very beginning of the illness as prior to antipsychotic use that may give opportunity to clinicians for earlier interventions regarding prevention of cardiometabolic events. In addition to waist size, the duration of illness was found to be an important predictor for MetS in schizophrenia in a large-scale meta-analysis study in $2013 .{ }^{27}$ Naturally, patients with first-episode psychosis are more frequently males than females, and females might be more liable to the metabolic side-effects of antipsychotic drugs and to the increment of waist circumference. Questionably, the antipsychotic drug use is increasing and reached top-selling drugs, surpassing lipid regulators or pump inhibitors in the USA in $2008 .{ }^{33}$ Although, the pathophysiology underlying MetS due to antipsychotic use is not clear, ${ }^{34}$ there are reasons to assume that treatment effects are related to the risk factors for cardiovascular problems. Interestingly, the studies about the influences of antipsychotics on cardiovascular problems do not exceed 1 year and patients who are compliant beyond 1 year might be underestimated. It is important to consider that individuals with schizophrenia may have a disadvantageous lifestyle that may lead to additional reasons for the development of MetS such as substance abuse, stress, inadequate self-care and unavailability of health care, financial problems, smoking, poor diet, low mobility, and lack of exercise, which are beyond this review.

According to the literature, to rank each antipsychotic for QTc prolongation risk seems difficult. Furthermore, the clinical significance for QT prolongation is unclear while QTc $>450 \mathrm{~ms}$ or $>30 \mathrm{~ms}$ prolongation of QTc versus baseline is widely accepted as important. Nevertheless, there are few studies investigating cardiac autonomic dysfunction prior to antipsychotic use or after introducing antipsychotic drugs in patients with first-episode psychosis in the literature. There is no reported case of TdP in therapeutic doses of antipsychotics except overdose conditions in the literature. Furthermore, the relation between atypical or typical antipsychotics and sudden cardiac death was questioned after Ray et al's published registry-based study that had reported similar rates of sudden deaths between atypical and typical drugs. ${ }^{75}$ However, this study is considerably criticized because of the definition of sudden death and inattentiveness for deaths due to secondary coronarymetabolic side effects. In general, atypical antipsychotics were thought to be safer than typical ones among the QTc interval or sudden deaths. ${ }^{47}$ Although the possible mechanism in the sex difference in the QTc interval among various antipsychotics remains unclear, the serum testosterone level is accused for QTc interval differences. ${ }^{76}$ However, in a few studies, no sex difference in QTc was demonstrated in various antipsychotic use such as depot, atypical, or typical; ${ }^{49,54,55}$ thus there might be some other determinants of QTc changes such as age (particularly, $>60$ years), drug interactions, and serum electrolytes (ie, hypokalemia or hypomagnesemia). ${ }^{56}$ Therefore, some new assessments might be conducted to determine the influences of antipsychotic drugs such as fragmented QRS or the T-wave peak to T-wave end (TpTe) interval and TpTe/QT, which have been accepted as predictors of ventricular arrhythmia more than QTc. ${ }^{77}$ In addition, the influence of antipsychotics on atrial conduction is very limited that may be observed on the PR interval or P-wave dispersion.

In the literature, a widely accepted etiologic factor for cardiomyopathy is the use of clozapine. The clozapine-induced immunoglobin E (IgE)-mediated hypersensitivity reaction, hyper-eosinophilic syndrome with direct cardiotoxic effects of eosinophils through the blockade of the cholinergic M2 receptor, and importantly, increase in noradrenalin after clozapine use than other antipsychotics were accounted for the clozapine-induced cardiomyopathy. ${ }^{64}$ In the literature, there are few individual case reports on cardiomyopathy due to other antipsychotics.

\section{Conclusion}

The studies and awareness about the physical needs of patients with schizophrenia are increasing, which had been neglected for a long time. The health care authorities or organizations are inviting physicians for increased cooperation and shared care between the different health care professionals to screen and treat CVD-risk factors, MetS, and diabetes in patients with psychiatric disorders because some risk factors of MetS or CVD are avoidable or at least modifiable to decrease high mortality in schizophrenia. These outcomes are reinforcing the importance of assessing all patients for cardiometabolic risk prior to and throughout treatment, choosing best fitting 
antipsychotics, and monitoring cardiometabolic adverse effects. Thus, aiming to realize this serious challenge, further understanding of the underlying mechanisms and improved CVD prevention and treatment are needed. Finally, these future research groups should focus on conducting an integrated system of studies based on a holistic biopsychosocial evaluation.

\section{Disclosure}

The authors report no conflicts of interest in this work.

\section{References}

1. Foley DL, Morley KI. Systematic review of early cardiometabolic outcomes of the first treated episode of psychosis. Arch Gen Psychiatry. 2011;68(6):609-616.

2. Correll CU, Robinson DG, Schooler NR, et al. Cardiometabolic risk in patients with first-episode schizophrenia spectrum disorders: baseline results from the RAISE-ETP study. JAMA Psychiatry. 2014; 71(12):1350-1363.

3. Ringen PA, Engh JA, Birkenaes AB, Dieset I, Andreassen OA. Increased mortality in schizophrenia due to cardiovascular disease - a non-systematic review of epidemiology, possible causes, and interventions. Front Psychiatry. 2014;5:137.

4. Ryan MC, Collins $P$, Thakore JH. Impaired fasting glucose tolerance in first-episode, drug-naïve patients with schizophrenia. Am J Psychiatry. 2003;160(2):284-289.

5. Raphael TP, Parsons JP. Blood sugar studies in dementia praecox and manic-depressive insanity. Arch Neurol Psychiatry. 1921;5:687-709.

6. Hansen T, Ingason A, Djurovic S, et al. At-risk variant in TCF7L2 for type II diabetes increases risk of schizophrenia. Biol Psychiatry. 2011;70(1):59-63.

7. Le Hellard S, Theisen FM, Haberhausen M, et al. Association between the insulin-induced gene 2 (INSIG2) and weight gain in a German sample of antipsychotic-treated schizophrenic patients: perturbation of SREBP-controlled lipogenesis in drug-related metabolic adverse effects? Mol Psychiatry. 2009;14(3):308-317.

8. Liou YJ, Bai YM, Lin E, et al. Gene-gene interactions of the INSIG1 and INSIG2 in metabolic syndrome in schizophrenic patients treated with atypical antipsychotics. Pharmacogenomics J. 2012;12(1):54-61.

9. Bai YM, Chen TT, Liou YJ, Hong CJ, Tsai SJ. Association between HTR2C polymorphisms and metabolic syndrome in patients with schizophrenia treated with atypical antipsychotics. Schizophr Res. 2011;125(2-3):179-186.

10. Burghardt K, Grove T, Ellingrod V. Endothelial nitric oxide synthetase genetic variants, metabolic syndrome and endothelial function in schizophrenia. J Psychopharmacol. 2014;28(4):349-356.

11. Chen X, Lee G, Maher BS, et al; GROUP Investigators; International Schizophrenia Consortium. GWA study data mining and independent replication identify cardiomyopathy-associated 5 (CMYA5) as a risk gene for schizophrenia. Mol Psychiatry. 2011;16(11):1117-1129.

12. Nicodemus KK, Law AJ, Radulescu E, et al. Biological validation of increased schizophrenia risk with NRG1, ERBB4, and AKT1 epistasis via functional neuroimaging in healthy controls. Arch Gen Psychiatry. 2010;67(10):991-1001.

13. Meyer D, Birchmeimer C. Multiple essential functions of neuregulin in development. Nature. 1995;378(6558):386-390.

14. Huertas-Vazquez A, Teodorescu C, Reinier K, et al. A common missense variant in the neuregulin 1 gene is associated with both schizophrenia and sudden cardiac death. Heart Rhythm. 2013;10(7):994-998.

15. Aberg K, Adkins DE, Liu Y, et al. Genome-wide association study of antipsychotic-induced QTc interval prolongation. Pharmacogenomics $J$. 2012;12(2):165-172.
16. Seven M, Karatas OF, Duz MB, Ozen M. The role of miRNAs in cancer: from pathogenesis to therapeutic implications. Future Oncol. 2014; 10(6): 1027-1048.

17. de Bartolomeis A, Iasevoli F, Tomasetti C, Buonaguro EF. MicroRNAs in schizophrenia: implications for synaptic plasticity and dopamineglutamate interaction at the postsynaptic density. New avenues for antipsychotic treatment under a theranostic perspective. Mol Neurobiol. Epub 2014 Nov 14.

18. Perkins DO, Jeffries CD, Jarskog LF, et al. microRNA expression in the prefrontal cortex of individuals with schizophrenia and schizoaffective disorder. Genome Biol. 2007;8(2):R27.

19. Gardiner E, Beveridge NJ, Wu JQ, et al. Imprinted DLK1-DIO3 region of $14 \mathrm{q} 32$ defines a schizophrenia-associated miRNA signature in peripheral blood mononuclear cells. Mol Psychiatry. 2012;17(8): $827-840$.

20. Santarelli DM, Liu B, Duncan CE, et al. Gene-microRNA interactions associated with antipsychotic mechanisms and the metabolic side effects of olanzapine. Psychopharmacology (Berl). 2013;227(1):67-78.

21. Gami AS, Witt BJ, Howard DE, et al. Metabolic syndrome and risk of incidence cardiovascular events and death: a systematic review and meta-analysis of longitudinal studies. J Am Coll Cardiol. 2007;49(4): 403-414.

22. Hanley AJ, Karter AJ, Williams K, et al. Prediction of type 2 diabetes mellitus with alternative definitions of the metabolic syndrome: the insulin resistance atherosclerosis study. Circulation. 2005;112(24): 3713-3721.

23. Saddichha S, Manjunatha N, Ameen S, Akhtar S. Effect of olanzapine, risperidone, and haloperidol treatment on weight and body mass index in first-episode schizophrenia patients in India: a randomized, doubleblind, controlled, prospective study. J Clin Psychiatry. 2007;68(11): 1793-1798.

24. Zhang ZJ, Yao ZJ, Liu W, Fang Q, Reynolds GP. Effects of antipsychotics on fat deposition and changes in leptin and insulin levels: magnetic resonance imaging study of previously untreated people with schizophrenia. Br J Psychiatry. 2004;184:58-62.

25. Ryan MC, Flanagan S, Kinsella U, Keeling F, Thakore JH. The effects of atypical antipsychotics on visceral fat distribution in first episode, drugnaïve patients with schizophrenia. Life Sci. 2004;74(16):1999-2008.

26. Fleischhacker WW, Siu CO, Bodén R, et al; EUFEST Study Group. Metabolic risk factors in first-episode schizophrenia: baseline prevalence and course analysed from the European First-Episode Schizophrenia Trial. Int J Neuropsychopharmacol. 2013;16(5):987-995.

27. Mitchell AJ, Vancampfort D, Sweers K, van Winkel R, Yu W, De Hert M. Prevalence of metabolic syndrome and metabolic abnormalities in schizophrenia and related disorders - a systematic review and meta-analysis. Schizophr Bull. 2013;39(2):306-318.

28. Van Gaal LF. Long-term health considerations in schizophrenia: metabolic effects and the role of abdominal adiposity. Eur Neuropsychopharmacol. 2006;16(suppl 3):S142-S148.

29. Ford ES, Giles WH, Dietz WH. Prevalence of the metabolic syndrome among US adults: findings from the third national health and nutrition examination survey. JAMA. 2002;287(3):356-359.

30. McEvoy JP, Meyer JM, Goff DC, et al. Prevalence of the metabolic syndrome in patients with schizophrenia: baseline results from the clinical antipsychotic trials of intervention effectiveness (CATIE) schizophrenia trial and comparison with national estimates from NHANES III. Schizophr Res. 2005;80(1):19-32.

31. Goff DC, Sullivan LM, McEvoy JP, et al. A comparison of ten-year cardiac risk estimates in schizophrenia patients from the CATIE study and matched controls. Schizophr Res. 2005;80(1):45-53.

32. Dixon L, Weiden P, Delahanty J, et al. Prevalence and correlates of diabetes in national schizophrenia samples. Schizophr Bull. 2000;26(4): 903-912.

33. Kuehn BM. Questionable antipsychotic prescribing remains common, despite serious risks. JAMA. 2010;303(16):1582-1584.

34. Raedler TJ. Cardiovascular aspects of antipsychotics. Curr Opin Psychiatry. 2010;23(6):574-581. 
35. Arranz B, San L, Dueñas RM, et al. Lower weight gain with the orally disintegrating olanzapine than with standard tablets in first-episode never treated psychotic patients. Hum Psychopharmacol. 2007;22(1): $11-15$.

36. McEvoy JP, Lieberman JA, Perkins DO, et al. Efficacy and tolerability of olanzapine, quetiapine, and risperidone in the treatment of early psychosis: a randomized, double-blind 52-week comparison. Am J Psychiatry. 2007;164(7):1050-1060.

37. Hägg S, Lindblom Y, Mjörndal T, Adolfsson R. High prevalence of the metabolic syndrome among a Swedish cohort of patients with schizophrenia. Int Clin Psychopharmacol. 2006;21(2):93-98.

38. Bär KJ. Cardiac autonomic dysfunction in patients with schizophrenia and their healthy relatives - a small review. Front Neurol. 2015;6:139.

39. Emul M, Dalkiran M, Coskun O, et al. P wave and QT changes among inpatients with schizophrenia after parenteral ziprasidone administration. Pharmacol Res. 2009;60(5):369-372.

40. Toichi M, Kubota Y, Murai T, et al. The influence of psychotic states on the autonomic nervous system in schizophrenia. Int J Psychophysiol. 1999;31(2):147-154.

41. Bär KJ, Berger S, Metzner M, et al. Autonomic dysfunction in unaffected first-degree relatives of patients suffering from schizophrenia. Schizophr Bull. 2010;36(5):1050-1058.

42. Jindal RD, Keshavan MS, EklundK, Stevens A, Montrose DM, Yeragani VK. Beat-to-beat heart rate and QT interval variability in first episode neuroleptic-naïve psychosis. Schizophr Res. 2009;113(2-3):176-180.

43. Valkonen-Korhonen M, Tarvainen MP, Ranta-Aho P, et al. Heart rate variability in acute psychosis. Psychophysiology. 2003;40(5):716-726.

44. Vrtovec B, Starc V, Starc R. Beat-to-beat QT interval variability in coronary patients. J Electrocardiol. 2000;33(2):119-125.

45. Chung AK, Chua SE. Effects on prolongation of Bazett's corrected QT interval of seven second-generation antipsychotics in the treatment of schizophrenia: a meta-analysis. J Psychopharmacol. 2011;25(5): 646-666.

46. Witchel HJ, Hancox JC, Nutt DJ. Psychotropic drugs, cardiac arrhythmia and sudden death. J Clin Psychopharmacol. 2003;23(1):58-77.

47. Zemrak WR, Kenna GA. Association of antipsychotic and antidepressant drugs with Q-T interval prolongation. Am J Health Syst Pharm. 2008;65(11):1029-1038.

48. Zhao T, Park TW, Yang JC, et al. Efficacy and safety of ziprasidone in the treatment of first-episode psychosis: an 8-week, open-label, multicenter trial. Int Clin Psychopharmacol. 2012;27(4):184-190.

49. Reilly JG, Ayis SA, Ferrier IN, Jones SJ, Thomas SH. QTc-interval abnormalities and psychotropic drug therapy in psychiatric patients. Lancet. 2000;355(9209):1048-1052.

50. Warner JP, Barnes TR, Henry JA. Electrocardiographic changes in patients receiving neuroleptic medication. Acta Psychiatr Scand. 1996; 93(4):311-313.

51. Harrigan EP, Miceli JJ, Anziano R, et al. A randomized evaluation of the effects of six antipsychotic agents on QTc, in the absence and presence of metabolic inhibition. J Clin Psychopharmacol. 2004;24(1):62-69.

52. Yang FD, Wang XQ, Liu XP, et al. Sex difference in QTc prolongation in chronic institutionalized patients with schizophrenia on long-term treatment with typical and atypical antipsychotics. Psychopharmacology (Berl). 2011;216(1):9-16.

53. Suzuki Y, Sugai T, Fukui N, et al. Sex differences in the effect of four second-generation antipsychotics on QTc interval in patients with schizophrenia. Hum Psychopharmacol. 2013;28(3):215-219.

54. Ozeki Y, Fujii K, Kurimoto N, et al. QTe prolongation and antipsychotic medications in a sample of 1,017 patients with schizophrenia. Prog Neuropsychopharmacol Biol Psychiatry. 2010;34(2):401-405.

55. Ramos-Ríos R, Arrojo-Romero M, Paz-Silva E, et al. QTc interval in a sample of long-term schizophrenia inpatients. Schizophr Res. 2010; 116(1):35-43.

56. Hasnain M, Vieweg WV. QTc interval prolongation and torsade de pointes associated with second-generation antipsychotics and antidepressants: a comprehensive review. CNS Drugs. 2014;28(10): 887-920.
57. Suzuki Y, Ono S, Tsuneyama N, et al. Effects of olanzapine on the PR and QT intervals in patients with schizophrenia. Schizophr Res. 2014; 152(1):313-314.

58. Cheng S, Keyes MJ, Larson MG, et al. Long-term outcomes in individuals with prolonged PR interval or first-degree atrioventricular block. JAMA. 2009;301(24):2571-2577.

59. Bayar R, Emül M, Turan S, et al. Electrocardiographical P wave changes after electroconvulsive therapy in patients with schizophrenia: a preliminary study. $J E C T$. 2009;25(1):26-30.

60. Tiihonen J, Lönnqvist J, Wahlbeck K, et al. 11-Year follow-up of mortality in patients with schizophrenia: a population-based cohort study (FIN11 study). Lancet. 2009;374(9690):620-627.

61. La Grenade L, Graham D, Trontell A. Myocarditis and cardiomyopathy associated with clozapine use in the United States. NEngl J Med. 2001; 345(3):224-225.

62. Alawami M, Wasywich C, Cicovic A, Kenedi C. A systematic review of clozapine induced cardiomyopathy. Int J Cardiol. 2014;176(2): 315-320.

63. Reinders J, Parsonage W, Lange D, Potter JM, Plever S. Clozapine related myocarditis and cardiomyopathy in an Australian metropolitan psychiatric service. Aust N Z J Psychiatry. 2004;38(11-12):915-922.

64. De Berardis D, Serroni N, Campanella D, et al. Update on the adverse effects of clozapine: focus on myocarditis. Curr Drug Saf. 2012; 7(1):55-62.

65. Brakoulias V, Bannan E, Cohen P, Geary G. Amisulpride and cardiomyopathy. Aust N Z J Psychiatry. 2005;39(8):738.

66. Bush A, Burgess C. Fatal cardiomyopathy due to quetiapine. NZMedJ. 2008;121(1268):U2909.

67. Roesch-Ely D, Van Einsiedel R, Kathöfer S, Schwaninger M, Weisbrod M. Myocarditis with quetiapine. Am J Psychiatry. 2002; 159(9):1607-1608.

68. Coffey S, Williams M. Quetiapine-associated cardiomyopathy. $N Z$ Med J. 2011;124(1337):105-107.

69. Bhatia MS, Gupta R, Dhawan J. Myocarditis after overdose of conventional antipsychotics. World J Biol Psychiatry. 2009;10(4 pt 2): 606-608.

70. Marti V. Sudden cardiac death due to risperidone therapy in a patient with possible hypertrophic cardiomyopathy. Ann Pharmacother. 2005;39(5):973.

71. Tay JK, Tan CH, Chong SA, Tan EC. Functional polymorphisms of the cytochrome P450 1A2 (CYP1A2) gene and prolonged QTc interval in schizophrenia. Prog Neuropsychopharmacol Biol Psychiatry. 2007; 31(6):1297-1302.

72. Christoforou N, Miller RA, Hill CM, Jie CC, McCallion AS, Gearhart JD. Mouse ES cell-derived cardiac precursor cells are multipotent and facilitate identification of novel cardiac genes. $J$ Clin Invest. 2008;118(3):894-903.

73. Andreassen OA, Thompson WK, Dale AM. Boosting the power of schizophrenia genetics by leveraging new statistical tools. Schizophr Bull. 2014;40(1):13-17.

74. Andreassen OA, Djurovic S, Thompson WK, et al; International Consortium for Blood Pressure GWAS, Diabetes Genetics Replication and Meta-analysis Consortium, Psychiatric Genomics Consortium Schizophrenia Working Group. Improved detection of common variants associated with schizophrenia by leveraging pleiotropy with cardiovascular-disease risk factors. Am J Hum Genet. 2013;92(2): 197-209.

75. Ray WA, Chung CP, Murray KT, Hall K, Stein CM. Atypical antipsychotic drugs and the risk of sudden cardiac death. $N$ Engl J Med. 2009;360(3):225-235.

76. van Noord C, Dörr M, Sturkenboom MC, et al. The association of serum testosterone levels and ventricular repolarization. Eur J Epidemiol. 2010;25(1):21-28.

77. Gupta P, Patel C, Patel H, et al. T (p-e)/QT ratio as an index of arrhythmogenesis. J Electrocardiol. 2008;41:567-574. 
Neuropsychiatric Disease and Treatment

Dovepress

\section{Publish your work in this journal}

Neuropsychiatric Disease and Treatment is an international, peerreviewed journal of clinical therapeutics and pharmacology focusing on concise rapid reporting of clinical or pre-clinical studies on a range of neuropsychiatric and neurological disorders. This journal is indexed on PubMed Central, the 'PsycINFO' database and CAS,

and is the official journal of The International Neuropsychiatric Association (INA). The manuscript management system is completely online and includes a very quick and fair peer-review system, which is all easy to use. Visit http://www.dovepress.com/testimonials.php to read real quotes from published authors.

Submit your manuscript here: http://www.dovepress.com/neuropsychiatric-disease-and-treatment-journal 